\author{
Ante Galić \\ predsjednik Visokog upravnog suda RH
}

\title{
KONTROLNI MEHANIZMI DJELOVANJA UPRAVNIH SUDOVA U REPUBLICI HRVATSKOJ
}

\author{
UDK: $342.9(497.5)$ \\ Pregledni znanstveni rad \\ Primljeno: 15. IX. 2015.
}

U ovom radu autor analizira kontrolne mehanizme djelovanja upravnih sudova sagledavajući ih u njihovoj slojevitosti i sveobuhvatnosti, kroz kontrolne mehanizme koji omogućuju kontrolu ustavnosti i zakonitosti odluka sudova te kontrolne mehanizme propisane organizacijskim propisima, čija je svrha kontrola zakonitosti rada sudaca i predsjednika sudova. Prvi spektar kontrolnih mehanizama uglavnom derivira iz temeljnog zakona kojim je reguliran upravni spor (Zakon o upravnim sporovima), a djelomice i iz odredaba Ustava i Ustavnog zakona o Ustavnom sudu Republike Hrvatske, dok je drugi spektar kontrolnih mehanizama arhetipski vezan za organizacijske propise. Iako ova dva spektra kontrolnih mehanizama generiraju iz različite vrste propisa, nedvojbeno je kako oni zajedno čine jednu komplementarnu cjelinu kontrolnih mehanizama.

\section{Ključne riječi: kontrolni mehanizmi, upravni sudovi, nadzor, ocjena} zakonitosti odluka, sudska uprava

\section{UVOD}

Analizirati kontrolne mehanizme djelovanja upravnih sudova znači, s jedne strane, analizirati mogućnosti kontrole odluka upravnih sudova donesenih u upravnosudskom nadzoru javne uprave, čiji je smisao zaštita prava i pravnih interesa građana $i$ društvenih subjekata povrijeđenih odlukama i drugim postupanjem upravnih tijela tj. tijela državne uprave i drugih državnih tijela jedinica lokalne i područne (regionalne) samouprave i pravnih osoba koje imaju javne ovlasti. Navedeni kontrolni mehanizmi propisani su Zakonom o upravnim sporovima (Narodne novine, broj: 20/10, 143/12 i 152/14) te Ustavnim zakonom o Ustavnom sudu Republike Hrvatske (Narodne novine, broj: 99/99, 29/02 i 49/02).

Međutim, s druge pak strane, u pravnom sustavu Republike Hrvatske postoji niz kontrolnih mehanizama propisanih organizacijskim propisima čija je svrha upravo kontrola zakonitosti rada sudova odnosno predsjednika i sudaca upravnih sudova (kao i svih ostalih sudova). Ta druga skupina kontrolnih mehanizama koji de facto omogućavaju kontrolu zakonitosti rada sudske uprave te kontrolu zakonitosti rada predsjednika sudova i sudaca, u širem smislu, propisana je organizacijskim propisima od kojih bismo apostrofirali Zakon o sudovima (Narodne novine, broj: 28/13, 33/15 i 82/15 - pročišćeni tekst), Sudski poslovnik (Narodne novine, broj: 37/14, 49/14, 8/15 i 35/15), Kodeks sudačke etike (Narodne novine, broj: 131/06) 
te pojedine odredbe Zakona o Državnom sudbenom vijeću (Narodne novine, broj: $116 / 10,57 / 11,130 / 11,13 / 13,28 / 13$ i 82/15) koje se odnose na stegovni postupak, razrješenje predsjednika sudova i sudaca i udaljenje od obavljanja dužnosti predsjednika sudova i sudaca.

Slijedom naprijed navedenoga, možemo zaključiti kako pravni poredak Republike Hrvatske poznaje dva spektra kontrolnih mehanizama djelovanja upravnih sudova koji se međusobno prožimaju i koji su komplementarni, a koji trebaju u konačnici osigurati sveobuhvatnu kontrolu zakonitosti djelovanja upravnih sudova, odnosno predsjednika i sudaca tih sudova.

Prvi spektar kontrolnih mehanizama propisan je osnovnim procesnim zakonom koji propisuje upravni spor u Republici Hrvatskoj, a to je Zakon o upravnim sporovima. Ovim zakonom propisana su pravna sredstva u obliku pravnih lijekova koji omogućavaju kontrolu zakonitosti odluka upravnih sudova pred višom nadležnom sudskom instancom te preispitivanje ustavnosti odluka upravnih sudova pred Ustavnim sudom Republike Hrvatske (koji postupak je propisan Ustavnim zakonom o Ustavnom sudu Republike Hrvatske).

Drugi spektar kontrolnih mehanizama djelovanja upravnih sudova, koji je propisan organizacijskim propisima (Zakon o sudovima, Zakon o Državnom sudbenom vijeću, Sudski poslovnik i Kodeks sudačke etike) obuhvaća kontrolne mehanizme koji trebaju osigurati efikasan nadzor zakonitosti rada sudske uprave odnosno kontrolu zakonitosti rada predsjednika sudova i sudaca. Spomenutim zakonima koji propisuju pojedine kontrolne mehanizme propisana je procedura $\mathrm{i}$ ovlaštenici kojima su dane ovlasti za aktiviranje kontrolnih mehanizama u svakom pojedinom slučaju. Tako je, primjerice, procesnim zakonom jasno propisano na koji se način može tražiti ocjenjivanje zakonitosti neke prvostupanjske odluke i tko je nadležan u takvom postupku odlučivati, dok su organizacijskim propisima jasno definirani uvjeti i postupak za razrješenje predsjednika suda ili suca.

\section{MOGUĆNOSTI KONTROLE ZAKONITOSTI ODLUKA UPRAVNIH SUDOVA PUTEM PRAVNIH LIJEKOVA}

Zakonom o upravnim sporovima ${ }^{1}$ koji je stupio na snagu 1. siječnja 2012. te Novelom Zakona o sudovima ${ }^{2}$ i Zakonom o područjima i sjedištima sudova ${ }^{3}$ u Republici Hrvatskoj je ustrojen novi sustav upravnih sudova kojim je prihvaćen model dvostupanjskog sudovanja (za razliku od dotadašnjeg modela koji je počivao na jednostupanjskom upravnom sudovanju). Uvođenje dvostupanjskog upravnog sudovanja predstavlja svakako jednu od najznačajnijih novina upravne reforme upravnog sudovanja koja je rezultirala donošenjem spomenutog Zakona o upravnim sporovima.

1 Zakon o upravnim sporovima (Narodne novine, broj: 20/10, 143/12 i 152/14).

Zakon o izmjenama i dopunama Zakona o sudovima (Narodne novine, broj: 153/09).

Zakon o područjima i sjedištima sudova (Narodne novine, broj: 144/10). 
Naime, u razdoblju pristupanja Republike Hrvatske i vođenju pregovora s Europskom unijom u okviru Poglavlja 23., koje se odnosilo na pravosuđe, bile su istaknute ozbiljne rezerve glede učinkovitosti tadašnje upravnosudske strukture s jednim upravnim sudom što jasno proizlazi iz izvješća koje je izradila misija stručnjaka za područje pravosuđa u svibnju 2005.

Prema tom izvješću upitno je, naime, može li tadašnja sudska struktura s jednim upravnim sudom jamčiti zadovoljavajući sudski nadzor odluka koje donose upravna tijela. Podsjetimo da je rezultat provedene reforme upravnog sudovanja, pored uvođenja upravnog sudovanja u dva stupnja, omogućavanje rješavanja spora po sucu pojedincu, proširenje predmeta upravnog spora, uvođenje mogućnosti nadzora zakonitosti općih akata jedinica lokalne i područne (regionalne) samouprave i pravnih osoba koje imaju javne ovlasti i pravnih osoba koje obavljaju pravnu službu, obveza utvrđivanja činjeničnog stanja i provođenje usmene rasprave od strane prvostupanjskih upravnih sudova, donošenje reformacijskih odluka te mogućnost pobijanja prvostupanjskih sudskih odluka u žalbenom postupku itd.

Zapravo sve nabrojene novine u upravnom sporu predstavljale su usklađivanje upravnog spora u Republici Hrvatskoj sa standardima Konvencije za zaštitu ljudskih prava i temeljnih sloboda, ${ }^{4}$ pravnom stečevinom Europske unije te sa zahtjevima i standardima unutarnjeg pravnog poretka (npr. potrebe propisivanja žalbenog postupka unutar upravnosudskog postupka sukladno zahtjevu Ustava Republike Hrvatske. ${ }^{5}$

Smisao nove organizacije upravnih sudova $u$ Republici Hrvatskoj $u$ dva stupnja jest $u$ tome da se osigura mogućnost izjavljivanja žalbe protiv odluka prvostupanjskih upravnih sudova te na taj način osigura efikasan mehanizam kontrole zakonitosti njihovih odluka. Iako je sam Zakon o upravnim sporovima, kakav je donesen u izvornom obliku propisao kroz „tzv. filtar za žalbu“ ${ }^{\text {“6 }}$ rigidno ograničenje mogućnosti aktiviranja žalbe kao kontrolnog mehanizma, sama mogućnost podnošenja žalbe protiv prvostupanjskih odluka donesenih u upravnom sporu predstavlja velik iskorak u domeni zaštite prava stranaka u upravnom sporu. Ovdje je također potrebno napomenuti da je kontrolni mehanizam žalbe važan komplement u ostvarivanju cilja Zakona o upravnim sporovima koji je definiran kao osiguranje zakonitosti sudske zaštite prava i pravnih interesa fizičkih i pravnih osoba i drugih stranaka povrijeđenih pojedinačnim odlukama ili postupanjem javnopravnih tijela. ${ }^{7}$ Pravne lijekove kao kontrolne mehanizme za ocjenjivanje zakonitosti odluka upravnih sudova, koji su propisani Zakonom o upravnim sporovima, možemo podijeliti u dvije kategorije i to kao redovne (žalba)

\footnotetext{
4 Konvencija za zaštitu ljudskih prava i temeljnih sloboda (Narodne novine - Međunarodni ugovori, broj: 18/97, 6/99, 14/02, 13/03, 9/05, 1/06 i 2/10).

5 Vidi članak 18., stavak 1. Ustava Republike Hrvatske (Narodne novine, broj: 85/10 - pročišćeni tekst i 5/14).

6 Vidi članak 66., stavak 2. Zakona o upravnim sporovima (Narodne novine, broj: 20/10).

7 Vidi članak 2., stavak 1. Zakona o upravnim sporovima.
} 
i izvanredne (obnova spora i zahtjev za izvanredno preispitivanje zakonitosti pravomoćne presude).

Značajan kontrolni mehanizam kojim je omogućeno ustavnosudsko preispitivanje ustavnosti odluka donesenih pred upravnim sudovima predstavlja institut ustavne tužbe sukladno odredbi članka 129. Ustava i odredbi članka 62. Ustavnog zakona o Ustavnom sudu Republike Hrvatske kojima su propisane ovlasti Ustavnog suda Republike Hrvatske da u svakom konkretnom slučaju potvrdi jesu li povrijeđena ustavom zajamčena prava podnositelja tužbe protiv odluke upravnog suda.

a) Žalbeni postupak kao kontrolni mehanizam ocjene zakonitosti odluka prvostupanjskih upravnih sudova

Kao što proizlazi iz naprijed navedenoga, kroz dvostupanjski sustav upravnih sudova trebala se osigurati veća efikasnost upravnog spora, naročito gledajući kroz zahtjev za većom zaštitom prava stranaka u upravnom sporu. Efikasnost upravnog spora osigurava se pravilima odnosno načelima prema kojima sud slobodno ocjenjuje dokaze i utvrđuje činjenice ${ }^{8}$ te nevezanost suda za činjenice utvrđene u postupku donošenja osporene odluke. ${ }^{9}$ Međutim težnja za što efikasnijim upravnim sporom nameće potrebu za mehanizmom koji će osigurati efikasnu i učinkovitu kontrolu zakonitosti odluka koje će prvostupanjski sudovi, očekivano, najčešće donositi korištenjem reformacijskih ovlaštenja. Da bi se osigurao što učinkovitiji upravni spor, pravo na podnošenje žalbi u izvornom tekstu Zakona o upravnim sporovima bilo je propisano na takav način i uz ograničenja, da se, pokazat će se u praksi, pravo na žalbu moglo vrlo restriktivno koristiti. Naime, prije donošenja druge Novele Zakona o upravnim sporovima, ${ }^{10}$ pravo na izjavljivanje žalbe bilo je ograničeno protiv rješenja prvostupanjskih upravnih sudova (moglo se podnositi samo kada je to bilo izričito propisano zakonom).

Drugo ograničenje prava na korištenje žalbe predstavljao je izuzetak od dvostupanjskog upravnog spora propisan posebnim zakonima prema kojima neke vrste upravnih sporova spadaju u prvostupanjsku nadležnost Visokog upravnog suda Republike Hrvatske. Najrigidnije ograničenje bilo je sadržano u „tzv. filtru za žalbu" kojim je bilo propisano da se žalba može izjaviti samo protiv one vrste presuda u kojima je upravni sud (prvostupanjski) sam odlučio o pravu, obvezi ili pravnom interesu stranke. U trogodišnjoj upravnosudskoj praksi prilično su se problematičnima za funkcioniranje i efikasnost novoustrojenog sustava upravnih sudova pokazali prvo i treće ograničenje za izjavljivanje žalbe, zbog čega su drugom Novelom Zakona o upravnim sporovima otklonjena ta ograničenja. Tom Novelom je propisano i pravo na žalbu protiv rješenja kojim sud ocjenjuje

8 Vidi članak 33., stavak 1. Zakona o upravnim sporovima.

9 Vidi članak 33., stavak 2. Zakona o upravnim sporovima.

10 Zakon o izmjenama i dopunama Zakona o upravnim sporovima (Narodne novine, broj: 152/14). 
pretpostavke za vođenje upravnog spora, ${ }^{11}$ te je propisan novi „filtar za žalbu“, odnosno propisani su novi liberalizirani kriteriji za ograničavanje prava na žalbu.

Potrebu za zakonodavnom intervencijom u smislu liberalizacije kriterija „filtra za žalbu“ najbolje potkrepljuju statistički podaci o broju odluka prvostupanjskih sudova u razdoblju primjene Zakona od tri godine protiv kojih je bilo moguće podnijeti žalbu.

Upravni sud u Zagrebu

\begin{tabular}{|c|c|c|c|}
\hline GOD. & $\begin{array}{c}\text { UKUPNO } \\
\text { RIJEŠ. }\end{array}$ & $\begin{array}{c}\text { DOPUŠ. } \\
\text { ŽALBA }\end{array}$ & $\begin{array}{c}\text { POSTO } \\
\%\end{array}$ \\
\hline 2012. & 1772 & 290 & 16,3 \\
\hline 2013. & 3617 & 560 & 15,4 \\
\hline 2014. & 3682 & 648 & 17,5 \\
\hline
\end{tabular}

Upravni sud u Rijeci

\begin{tabular}{|l|c|c|c|}
\hline GOD. & $\begin{array}{c}\text { UKUPNO } \\
\text { RIJES. }\end{array}$ & $\begin{array}{c}\text { DOPUŠ. } \\
\text { ŽALBA }\end{array}$ & $\begin{array}{c}\text { POSTO } \\
\%\end{array}$ \\
\hline 2012. & 483 & 155 & 32 \\
\hline 2013. & 1129 & 268 & 23,7 \\
\hline 2014. & 1778 & 307 & 17,2 \\
\hline
\end{tabular}

Upravni sud u Splitu

\begin{tabular}{|l|c|c|c|}
\hline GOD. & $\begin{array}{c}\text { UKUPNO } \\
\text { RIJEŠ. }\end{array}$ & $\begin{array}{c}\text { DOPUŠ. } \\
\text { ŽALBA }\end{array}$ & $\begin{array}{c}\text { POSTO } \\
\%\end{array}$ \\
\hline 2012. & 434 & 73 & 16,8 \\
\hline 2013. & 1134 & 433 & 38,1 \\
\hline 2014. & 1882 & 360 & 19,1 \\
\hline
\end{tabular}

Upravni sud u Osijeku

\begin{tabular}{|l|c|c|c|}
\hline GOD. & $\begin{array}{c}\text { UKUPNO } \\
\text { RIJEŠ. }\end{array}$ & $\begin{array}{c}\text { DOPUŠ. } \\
\text { ŽALBA }\end{array}$ & $\begin{array}{c}\text { POSTO } \\
\%\end{array}$ \\
\hline 2012. & 688 & 65 & 9,4 \\
\hline 2013. & 1562 & 136 & 8,7 \\
\hline 2014. & 1745 & 99 & 5,6 \\
\hline
\end{tabular}

Tabelarni prikaz ukupno riješenih predmeta po prvostupanjskim sudovima s brojem predmeta $u$ kojima je bilo dopušteno podnijeti žalbu

Usporedbom pravnih sustava unutar zemalja članica Europske unije može se zaključiti kako Republika Hrvatska u pogledu definiranja samih žalbenih razloga (bitne povrede pravila sudskog postupka, pogrešno ili nepotpuno utvrđenog činjenog stanja, pogrešne primjene materijalnog prava) ${ }^{12}$ spada među zemlje koje imaju najširi okvir žalbenih razloga (npr. Italija, Grčka, Finska, Slovačka i Litva) što omogućava visoku razinu zaštite subjektivnih prava u upravnom sporu. Međutim, u praksi se pokazalo da ovako široki okvir žalbenih razloga sam po sebi ne može jamčiti i djelotvornu zaštitu subjektivnih prava ukoliko postoji „filtar“ koji rigidno reducira mogućnost korištenja žalbe kao pravnog sredstva. Analizom usporednih pravnih sustava također možemo doći do zaključka kako filtriranje žalbi nije nepoznato brojnim pravnim sustavima zemalja članica Europske unije,

11 Pretpostavke za vođenje upravnog spora određene su člankom 30., stavak 1. Zakona o upravnim sporovima kojim je propisano da će sud rješenjem odbaciti tužbu jer ne postoje pretpostavke za vođenje upravnog spora ako utvrdi da je tužba podnesena nepravodobno ili prijevremeno (točka 1.), da se pojedinačnom odlukom, postupanjem ili upravnim ugovorom ne dira u pravo ili pravni interes tužitelja (točka 2.), da protiv pojedinačne odluke, postupanja ili upravnog ugovora nije iskorišten redovit pravni lijek (točka 3.), da je sudska zaštita osigurana izvan upravnog spora (točka 4.), da već postoji pravomoćna odluka donesena u upravnom sporu u istoj stvari (točka 5.), da je tužba podnesena protiv postupovne odluke, osim ako zakonom nije drukčije propisano (točka 6.), da je tužba podnesena u stvari koja ne može biti predmet upravnog spora (točka 7.).

12 Vidi članak 66., stavak 1. Zakona o upravnim sporovima. 
bilo da je ograničeno mogućnošću podnošenja žalbe (npr. Italija, Belgija, Portugal, Estonija, Bugarska, Ujedinjeno Kraljevstvo i Irska), bilo da se traži posebna dozvola za izjavljivanje žalbe (npr. Švedska i Finska). ${ }^{13}$

Upravo iskustva iz usporednih pravnih sustava potvrđuju da tzv. „filtriranje žalbe" ne znači samo po sebi reduciranje mogućnosti korištenja subjektivnih prava već je ključ uspjeha koje omogućuje korištenje žalbe kao efikasnog kontrolnog mehanizma i ograničavanja žalbe putem „filtra“, sadržan u balansu kriterija za filtriranje žalbe. Zbog toga su zakonodavnom intervencijom (koja je producirala drugom Novelom Zakona o upravnim sporovima, donesenom 12. prosinca 2014.) propisani novi kriteriji za filtriranje žalbi koji su definirani po sistemu negativne enumeracije tako da ,žalba nije dopuštena protiv presude kojom je pojedinačna odluka javnopravnog tijela poništena ili oglašena ništavom i predmet prvi put vraćen na ponovni postupak, kao ni protiv presude kojom je sud naložio donošenje pojedinačne odluke koja nije donesena u propisanom roku te protiv dijela presude iz članka 89. stavka 4. ovog Zakona u koji je uključen sadržaj sudske nagodbe“. ${ }^{14}$

Statistički podaci o radu prvostupanjskih upravnih sudova u prvih osam mjeseci 2015. (nakon donošenja druge Novele Zakona o upravnim sporovima kojim je liberaliziran ,filtar na žalbu“) pokazuju da se broj odluka prvostupanjskih upravnih sudova protiv kojih je bilo moguće podnijeti žalbu više nego učetverostručio (u ranijem se razdoblju žalba mogla izjavljivati u prosjeku protiv $17 \%$ donesenih odluka prvostupanjskih upravnih sudova). Naime, iz navedenih podataka proizlazi da je u navedenom razdoblju doneseno na svim upravnim sudovima prosječno $70,7 \%$ odluka protiv kojih je bilo dopušteno podnijeti žalbu jer je od ukupno donesenih 5923 odluke, protiv 4192 odluke svih prvostupanjskih upravnih sudova u Republici Hrvatskoj bilo dopušteno podnijeti žalbu.

Upravni sud u Zagrebu

\begin{tabular}{|c|c|c|c|}
\hline $\begin{array}{c}\text { Razdoblje nakon } \\
\text { druge novele } \\
\text { ZUS-a }\end{array}$ & $\begin{array}{c}\text { UKUPNO } \\
\text { RIJES. }\end{array}$ & $\begin{array}{c}\text { DOPUŠ. } \\
\text { ŽALBA }\end{array}$ & $\begin{array}{c}\text { POSTO } \\
\%\end{array}$ \\
\hline $\begin{array}{c}\text { 1. 1.2015. - } \\
\text { 31. 8. 2015. }\end{array}$ & 2396 & 1715 & 71,5 \\
\hline
\end{tabular}

\section{Upravni sud u Rijeci}

\begin{tabular}{|c|c|c|c|}
\hline $\begin{array}{c}\text { Razdoblje nakon } \\
\text { druge novele } \\
\text { ZUS-a }\end{array}$ & $\begin{array}{c}\text { UKUPNO } \\
\text { RIJEŠ. }\end{array}$ & $\begin{array}{c}\text { DOPUŠ. } \\
\text { ŽALBA }\end{array}$ & $\begin{array}{c}\text { POSTO } \\
\%\end{array}$ \\
\hline $\begin{array}{c}\text { 1. 1.2015. - } \\
\text { 31.8.2015. }\end{array}$ & 1106 & 801 & 72,4 \\
\hline
\end{tabular}

Upravni sud u Osijeku
\begin{tabular}{|c|c|c|c|}
\hline $\begin{array}{c}\text { Razdoblje nakon } \\
\text { druge } \\
\text { novele ZUS-a }\end{array}$ & $\begin{array}{c}\text { UKUPNO } \\
\text { RIJEŠ. }\end{array}$ & $\begin{array}{c}\text { DOPUŠ. } \\
\text { ŽALBA }\end{array}$ & $\begin{array}{c}\text { POSTO } \\
\%\end{array}$ \\
\hline $\begin{array}{c}\text { 1. 1. 2015. - } \\
\text { 31. 8. 2015. }\end{array}$ & 1013 & 780 & 76,9 \\
\hline
\end{tabular}

Upravni sud u Splitu

\begin{tabular}{|c|c|c|c|}
\hline $\begin{array}{c}\text { Razdoblje nakon } \\
\text { druge } \\
\text { novele ZUS-a }\end{array}$ & $\begin{array}{c}\text { UKUPNO } \\
\text { RIJEŠ. }\end{array}$ & $\begin{array}{c}\text { DOPUŠ. } \\
\text { ŽALBA }\end{array}$ & $\begin{array}{c}\text { POSTO } \\
\%\end{array}$ \\
\hline $\begin{array}{c}\text { 1.1.2015. - } \\
\text { 31.8.2015. }\end{array}$ & 1408 & 896 & 63,6 \\
\hline
\end{tabular}

Tabelarni prikaz ukupno riješenih predmeta na upravnim sudovima s brojem predmeta protiv kojih je u prvih osam mjeseci 2015. bilo dopušteno podnijeti žalbu

13 Žalba u upravnom sporu - vidi u: doc. dr. sc. Dario Đerđa/Ante Galić, Zbornik radova Pravnog fakulteta u Splitu, god.: 51/2014., br. 2 (112).

14 Vidi članak 66.a, stavak 1. i 2. Zakona o upravnim sporovima. 
Slijedom navedenoga proizlazi zaključak da je liberalizacijom „filtra za žalbu“ postignut jedan od osnovnih ciljeva druge Novele Zakona o upravnim sporovima da se omogućavanjem aktiviranja žalbenog postupka kao najefikasnijeg mehanizma kontrole zakonitosti rada prvostupanjskih sudova osigura veća razina zaštite subjektivnih prava, odnosno veća zaštita pravne sigurnosti u upravnom sporu. ${ }^{15}$

Iskustva u različitim pravnim sustavima, pa tako i u Republici Hrvatskoj, pokazuju da je žalba kao redovan i univerzalan pravni lijek o kojem odlučuje viša sudska instanca u sudbenom hijerarhiji (što je čini i devolutivnim pravnim lijekom) najučinkovitiji kontrolni mehanizam zakonitosti odluka prvostupanjskih upravnih sudova. To je uvjetovano širokim spektrom žalbenih razloga i širokom mogućnošću korištenja ovog pravnog sredstva što proizlazi iz prije navedenih statističkih podataka.

Prema odredbama Zakona o upravnim sporovima, odluke drugostupanjskog suda po žalbi mogu biti procesne (kojima se rješenjem žalba odbacuje kao nedopuštena, bilo da je nepravodobna, podnesena od neovlaštene osobe ili neuredna) ili meritorne (drugostupanjski sud će presudom žalbu odbiti kao neosnovanu i potvrditi prvostupanjsku presudu kad utvrdi da ne postoje razlozi zbog kojih se presuda pobija ili da oni ne utječu na donošenje drugačije presude ili će poništiti prvostupanjsku presudu te će sam otkloniti nedostatke i presudom riješiti stvar ako utvrdi da je upravni sud počinio bitnu povredu pravila sudskog postupka, da je pogrešno ili nepotpuno utvrdio činjenično stanje ili da je pogrešno primijenio materijalno pravo). ${ }^{16}$

Obveza žalbenog suda koja proizlazi iz odredbe članka 74., stavak 2. Zakona o upravnim sporovima da sam otkloni nedostatke i presudom sam riješi stvar, rezultat je nagnuća zakonodavca za efikasnošću upravnog spora koji bi se po tom modelu trebao okončati pred Visokim upravnim sudom Republike Hrvatske kao najvišom sudbenom instancom u upravnom sudovanju. Međutim, nametanje obveze višoj sudbenoj instanci da korištenjem reformacijskih ovlasti de facto supstituira prvostupanjski sud predstavlja veliko opterećenje. Ta obveza može prouzročiti komplikacije kako u tehničkom smislu, s obzirom na mjesnu nadležnost Visokog upravnog suda Republike Hrvatske koji pokriva nadležnost cijele države, tako i u sadržajnom smislu s obzirom na nemogućnost rješavanja upravnih stvari korištenjem reformacijskih ovlasti gdje postoji zapreka s obzirom na prirodu stvari ili s obzirom na činjenicu da je tuženik rješavao po slobodnoj ocjeni.

Osim toga, analizom usporednih pravnih sustava zemalja članica Europske unije možemo zaključiti kako ovakav model koji nameće žalbenom sudu obvezu „,imperativnog korištenja reformacijskih ovlasti“ ne postoji ni u jednom pravnom sustavu.

15 Žalba u upravnom sporu - vidi u: doc. dr. sc. Dario Đerđa/Ante Galić, Zbornik radova Pravnog fakulteta u Splitu, god.: 51/2014., br. 2 (112).

16 Vidi članak 74., stavak 1. i 2. Zakona o upravnim sporovima. 
U drugim sličnim postupcima u Republici Hrvatskoj (kao što su parnični i kazneni) također ne postoje procesni imperativi koji nameću drugostupanjskom (žalbenom) sudu obvezu da u žalbenom postupku sam otklanja nedostatke koje je uočio u postupanju suda prvog stupnja. Ova obveza Visokog upravnog suda Republike Hrvatske, koja proizlazi iz odredbe članka 74., stavak 2. Zakona o upravnim sporovima, potiskuje u drugi plan izvorno prioritetne zadaće više sudbene instance da putem primjedbi i uputa za rad u konkretnom predmetu u kojem se ocjenjuje zakonitost neke odluke u žalbenom postupku, ukazuje na uočene nedostatke i nepravilnosti u radu nižoj sudskoj instanci te da ujednačava ukupnu sudsku praksu.

Stoga smatram da će se u budućnosti trebati razmisliti o tome da se ova obveza imperativnog korištenja reformacijskih ovlasti preformulira u alternativnu mogućnost korištenja reformacijskih ovlasti ili da se jednostavno sadržaj reformacije formulira na adekvatan način (kroz sudsku praksu).

Što se tiče predmeta koje u prvom stupnja rješava Visoki upravni sud RH i koji su po svojoj prirodi, kao takvi posebnim zakonima izuzeti iz režima drugostupanjskog upravnog sudovanja, možemo reći da oni ne participiraju u značajnijem broju jer na godišnjoj razini njihov priljev čini manje od $1 \%$ u ukupnom broju predmeta (tako je primjerice tijekom 2012. zaprimljeno 47 predmeta ili 0,29 \% od ukupno 15.912 predmeta, tijekom 2013. zaprimljeno je 125 predmeta ili $0,75 \%$ od ukupno 16.617 predmeta te tijekom 2014. zaprimljeno je 108 predmeta ili $0,68 \%$ od ukupno 15.781 predmeta).

b) Postupci po izvanrednim pravnim lijekovima kao kontrolni mehanizmi ocjene zakonitosti upravnih sudova

Zakon o upravnim sporovima pored žalbenog postupka propisuje mogućnosti korištenja izvanrednih pravnih lijekova koje također možemo kategorizirati kao kontrolne mehanizme koji omogućavaju kontrolu zakonitosti upravnosudskih odluka.

Tako su zakonom kao izvanredna pravna sredstva propisani obnova spora ${ }^{17} \mathrm{i}$ zahtjev za izvanredno preispitivanje zakonitosti pravomoćne presude. ${ }^{18}$

Dosezi obnove spora kao kontrolnog mehanizma reducirani su na zakonom taksativno nabrajane situacije propisane člankom 76., stavak 1. Zakona o upravnim sporovima tako da se spor okončan presudom može obnoviti na prijedlog stranke samo u situacijama ako je konačnom presudom Europskog suda za ljudska prava odlučeno o povredi temeljnog ljudskog prava ili slobode na drukčiji način od presude suda (točka 1.), ako se presuda temelji na prethodnom pitanju, a nadležni sud ili drugo javnopravno tijelo o tom je pitanju poslije odlučilo u bitnim točkama drukčije (točka 2.), ako je do odluke suda došlo zbog kaznenog djela suca ili službenika suda (točka 3.), ako se odluka suda temelji na ispravi koja je

\footnotetext{
17 Vidi članak 76. i 77. Zakona o upravnim sporovima.

18 Vidi članak 78. Zakona o upravnim sporovima.
} 
krivotvorena ili u kojoj je ovjeren neistinit sadržaj, ili ako se odluka suda temelji na lažnom iskazu svjedoka, vještaka ili stranke (točka 4.), ako je u donošenju odluke sudjelovao sudac koji je prema članku 15. ovoga Zakona morao biti izuzet (točka 5.), ako stranka sazna za nove činjenice ili nađe ili stekne mogućnost da upotrijebi nove dokaze na temelju kojih bi spor bio povoljnije riješen za nju da su te činjenice, odnosno dokazi bili izneseni ili upotrijebljeni u prijašnjem sudskom postupku (točka 6.), ako zainteresiranoj osobi nije bila dana mogućnost da sudjeluje u upravnom sporu (točka 7.).

Iz naprijed navedenoga može se zaključiti da se ovim pravnim sredstvom ne mogu otklanjati druge nezakonitosti.

Odredbom članka 76., stavak 2. propisano je da se prijedlog za obnovu spora podnosi sudu koji je donio presudu (što znači da to može biti bilo prvostupanjski ili drugostupanjski sud) u roku od 30 dana od dana kada je stranka saznala za razlog obnove, a nakon proteka jedne godine od pravomoćnosti presude obnova se ne može predložiti iz prije citiranih razloga propisanih točkama 5., 6. i 7. ovoga članka.

Odredbama članka 77. Zakona propisano je postupanje suda po prijedlogu za obnovu spora te je tako propisano da će sud odbaciti prijedlog rješenjem ukoliko utvrdi da je prijedlog podnijela neovlaštena osoba ili je prijedlog nepravodoban ili stranka nije učinila vjerojatnim postojanje zakonske osnove za obnovu (stavak 1.). Ukoliko, međutim, sud ne odbaci prijedlog, dostavit će ga drugim strankama te ih pozvati da u roku od 15 dana odgovore na prijedlog (stavak 2.), a ako se obnova dopusti, prijašnja odluka stavit će se izvan snage u cijelosti ili djelomično, a prijašnje postupovne radnje na koje ne utječu razlozi obnove neće se obnavljati te će se presudom kojom se obnova dopušta odlučiti o predmetu spora (stavak 3.). Nastavno iznosim statističke podatke o broju podnesenih prijedloga za obnovu spora pred upravnim sudovima, uz napomenu da su ovakvi postupci vođeni na upravnim sudovima u Zagrebu, Rijeci i Splitu.

Upravni sud u Zagrebu

\begin{tabular}{|c|c|c|c|c|c|c|c|}
\hline Razdoblje & PRIMLJENO & RIJEŠENO & ODBAČENO & ODBIJENO & OBUSTAVLJENO & USTUPLJENO & NERIJEŠENO \\
\hline $\begin{array}{c}1.1 .2012 . \\
-31.8 .2015\end{array}$ & 38 & 37 & 17 & - & - & 20 & 1 \\
\hline
\end{tabular}

Upravni sud u Rijeci

\begin{tabular}{|c|c|c|c|c|c|c|c|}
\hline Razdoblje & PRIMLJENO & RIJEŠENO & ODBAČENO & ODBIJENO & OBUSTAVLJENO & USTUPLJENO & NERIJEŠENO \\
\hline $\begin{array}{c}1.1 .2012 . \\
-31.8 .2015 .\end{array}$ & 21 & 16 & 14 & 1 & 1 & - & 5 \\
\hline
\end{tabular}


Upravni sud u Splitu

\begin{tabular}{|l|c|c|c|c|c|c|c|}
\hline Razdoblje & PRIMLJENO & RIJEŠENO & ODBAČENO & ODBIJENO & OBUSTAVLJENO & USTUPLJENO & NERIJEŠENO \\
\hline $\begin{array}{l}\text { 1.1.2012. } \\
-31.8 .2015 .\end{array}$ & 6 & 3 & 3 & - & - & - & 3 \\
\hline
\end{tabular}

Tabelarni prikaz ukupno podnesenih prijedloga za obnovu spora pred upravnim sudovima

Zahtjev za izvanredno preispitivanje zakonitosti pravomoćne presude kao kontrolni mehanizam temeljem kojeg bi se ocjenjivala zakonitost neke odluke upravnih sudova, stranke koje su nezadovoljne odlukama upravnih sudova mogu samo posebno aktivirati da bi zaštitile svoja prava i pravne interese.

Naime, odredbama članka 78. Zakona o upravnim sporovima ${ }^{19}$ propisana je procedura za podnošenje i odlučivanje o zahtjevu za izvanredno preispitivanje zakonitosti pravomoćne presude. Tako je odredbama spomenutog članka Zakona propisano da stranke u upravnom sporu mogu zbog povrede zakona predložiti Državnom odvjetništvu Republike Hrvatske podnošenje zahtjeva za izvanredno preispitivanje zakonitosti pravomoćne presude i rješenja upravnog suda ili Visokog upravnog suda Republike Hrvatske (stavak 1). ${ }^{20}$ Ovaj zahtjev može podnijeti Državno odvjetništvo Republike Hrvatske u roku od šest mjeseci od dana donošenja pravomoćne sudske presude strankama s tim da isto tijelo (Državno odvjetništvo Republike Hrvatske) zahtjev može podnijeti i ex offo. ${ }^{21} \mathrm{O}$ zahtjevu odlučuje Vrhovni sud Republike Hrvatske u vijeću od pet sudaca ${ }^{22}$ koji o zahtjevu rješava na nejavnoj sjednici, a pobijanu odluku ispituje samo u granicama zahtjeva. ${ }^{23}$ Ukoliko Vrhovni sud Republike Hrvatske usvoji zahtjev, može ukinuti presudu i vratiti predmet na ponovno rješavanje ili preinačiti presudu. ${ }^{24}$

Ovaj izvanredni pravni lijek je uz Zakon o upravnim sporovima stipuliran u završnoj fazi izrade zakona (zbog dvojbi oko koncepta uređenja organizacije upravnog sudovanja u Republici Hrvatskoj) sa ciljem „osiguranja Ustavom Republike Hrvatske utvrđene jedinstvene primjene zakona i ravnopravnosti građana". ${ }^{25}$

Korištenje ovog izvanrednog pravnog sredstva prilično je ograničeno definirano zakonom, zbog čega kao kontrolni mehanizam djelovanje upravnih sudova, kroz kontrolu zakonitosti njihovih odluka nije do sada polučio neke rezultate, što nedvosmisleno potkrepljuju statistički pokazatelji o broju i rezultatima pokrenutih postupaka o zahtjevima za izvanredno preispitivanje

\footnotetext{
19 Vidi članak 78. Zakona o upravnim sporovima.

20 Vidi članak 78., stavak 1. Zakona o upravnim sporovima.

21 Vidi članak 78., stavak 2. Zakona o upravnim sporovima.

22 Vidi članak 78., stavak 3. Zakona o upravnim sporovima.

23 Vidi članak 78., stavak 6. Zakona o upravnim sporovima.

24 Vidi članak 78., stavak 8. Zakona o upravnim sporovima.

25 Obrazloženje Konačnog prijedloga Zakona o upravnim sporovima sa 16. sjednice Hrvatskog
} sabora. Mrežna stanica http\www.sabor.hr 
zakonitosti pravomoćne presude, od početka primjene Zakona o upravnim sporovima do danas.

Upravni sud u Zagrebu

\begin{tabular}{|l|c|c|c|c|c|}
\hline Razdoblje & PRIMLJENO & RIJEŠENO & UKINUTO & ODBAČENO & NERIJEŠENO \\
\hline $\begin{array}{l}1.1 .2012 . \\
-\end{array}$ & 5 & 4 & 2 & 2 & 1 \\
31.8 .2015$. & & & & & \\
\hline
\end{tabular}

Upravni sud u Rijeci

\begin{tabular}{|l|c|c|c|c|c|}
\hline Razdoblje & PRIMLJENO & RIJEŠENO & UKINUTO & ODBAČENO & NERIJEŠENO \\
\hline 1.1 .2012$. & & & & 1 & \\
\hline 31.8.2015. & 2 & 2 & 1 & & - \\
\hline
\end{tabular}

Upravni sud u Osijeku

\begin{tabular}{|l|c|c|c|c|c|}
\hline Razdoblje & PRIMLJENO & RIJEŠENO & UKINUTO & ODBAČENO & NERIJEŠENO \\
\hline $\begin{array}{c}1.1 .2012 . \\
-\end{array}$ & 4 & 1 & 1 & - & 3 \\
31.8 .2015$. & 4 & 1 & & \\
\hline
\end{tabular}

Tabelarni prikaz podnesenih prijedloga za izvanredno preispitivanje zakonitosti pravomoćne presude pred upravnim sudovima

U postupcima noveliranja Zakona o upravnim sporovima razvidno je da je zakonodavac bio u dilemi treba li korištenje ovog izvanrednog pravnog sredstva usmjeriti i dopustiti protiv svih odluka koje donose upravni sudovi ili samo protiv presuda, da bi potonjom novelom Zakona o upravnim sporovima bilo propisano da se može preispitivati zakonitost i presuda i rješenja upravnih sudova.

c) Ustavnosudska kontrola odluka upravnih sudova

U okviru svoje nadležnosti da postupa po ustavnim tužbama podnesenima radi zaštite ljudskih prava i temeljnih sloboda, Ustavni sud Republike Hrvatske provodi ustavnosudsku kontrolu odluka upravnih sudova.

Naime, odredba članka 62., stavak 1. Ustavnog zakona o Ustavnom sudu Republike Hrvatske ${ }^{26}$ propisuje da svatko može podnijeti Ustavnom sudu ustavnu tužbu ako smatra da mu je pojedinačnim aktom tijela državne vlasti, tijela jedinice lokalne i područne (regionalne) samouprave ili pravne osobe s javnim ovlastima, kojim je odlučeno o njegovim pravima i obvezama ili o sumnji ili optužbi zbog kažnjivog djela, povrijeđeno ljudsko pravo ili temeljna sloboda zajamčena ustavom odnosno ustavom zajamčeno pravo na lokalnu i područnu (regionalnu) samoupravu (ustavno pravo).

26 Vidi članak 62., stavak 1. Ustavnog zakona o Ustavnom sudu Republike Hrvatske. 
Dakle, ovdje se radi o pravnom sredstvu usmjerenom na zaštitu ustavnih prava, koje se može aktivirati pod određenim pretpostavkama što ih propisuje citirani Ustavni zakon.

Tako je odredbom članka 62., stavka 2. citiranog Ustavnog zakona ${ }^{27}$ propisano da ako je zbog povrede ustavnih prava dopušten drugi pravni put, ustavna tužba može se podnijeti tek nakon što je taj pravni put iscrpljen. Izuzetak od ovog pravila propisuje odredba članka 63., stavak 1. citiranog Ustavnog zakona ${ }^{28}$ u kojoj se navodi da će Ustavni sud pokrenuti postupak po ustavnoj tužbi i prije no što je iscrpljen pravni put, u slučaju kad o pravima i obvezama stranke ili o sumnji ili optužbi zbog kažnjivog djela nije u razumnom roku odlučio sud ili u slučaju kad se osporenim pojedinačnim aktom grubo vrijeđaju ustavna prava, a potpuno je razvidno da bi nepokretanjem ustavnosudskog postupka za podnositelja ustavne tužbe mogle nastati teške i nepopravljive posljedice.

Prema egzaktnim statističkim pokazateljima, Ustavni sud je prosječno godišnje usvajao $5-8 \%$ ustavnih tužbi, ${ }^{29}$ a prema najnovijim podacima, dobivenima od glavnog tajništva Ustavnog suda, proizlazi da je od 2014. ukupni broj svih ukidnih odluka po ustavnim tužbama smanjen na prosječno $3-4 \%$. Međutim, isto tako prema statističkim podacima upravnih sudova proizlazi da je u svim postupcima po ustavnim tužbama protiv odluka upravnih sudova usvojeno prosječno u navedenom razdoblju (od 1. siječnja 2012. do 31. kolovoza 2015.) 1,5\% ustavnih tužbi, što je znatno ispod spomenutog prosjeka.

Visoki upravni sud Republike Hrvatske

\begin{tabular}{|c|c|c|c|c|c|c|}
\hline & $\begin{array}{c}\text { UKUPNO } \\
\text { PODNESENO } \\
\text { USTAVNIH } \\
\text { TUŽBI }\end{array}$ & UKINUTO & $\begin{array}{c}\text { POTVRĐENO } \\
\text { - ODBIJENO }\end{array}$ & ODBAČENO & OBUSTAVLJENO & NERIJEŠENO \\
\hline 1.1 .2012$. & & - & 9 & 156 & - & 122 \\
\hline-31.8 .2015$. & 287 & - & & & & \\
\hline
\end{tabular}

Upravni sud u Zagrebu

\begin{tabular}{|c|c|c|c|c|c|c|}
\hline GOD. & $\begin{array}{c}\text { UKUPNO } \\
\text { PODNESENO } \\
\text { USTAVNIH } \\
\text { TUŽBI }\end{array}$ & UKINUTO & $\begin{array}{c}\text { POTVRĐENO } \\
\text { - ODBIJENO }\end{array}$ & ODBAČENO & OBUSTAVLJENO & NERIJEŠENO \\
\hline $\begin{array}{c}1.1 .2012 . \\
-31.8 .2015\end{array}$ & 610 & 10 & 29 & 482 & 9 & 80 \\
\hline
\end{tabular}

27 Vidi članak 62., stavak 2. Ustavnog zakona o Ustavnom sudu Republike Hrvatske.

28 Vidi članak 63., stavak 1. Ustavnog zakona o Ustavnom sudu Republike Hrvatske.

29 „Položaj Ustavnog suda Republike Hrvatske u odlučivanju u upravnim stvarima“ - prof. dr. sc. Aldo Radolović, Upravno pravo - Aktualnosti upravnog sudovanja i upravne prakse - 2008., Inženjerski biro 2008. 
Upravni sud u Splitu

\begin{tabular}{|c|c|c|c|c|c|c|}
\hline GOD. & $\begin{array}{c}\text { UKUPNO } \\
\text { PODNESENO } \\
\text { USTAVNIH } \\
\text { TUŽBI }\end{array}$ & UKINUTO & $\begin{array}{c}\text { POTVRĐENO } \\
\text { - ODBIJENO }\end{array}$ & ODBAČENO & OBUSTAVLJENO & NERIJEŠENO \\
\hline 1.1 .2012$. & & 2 & 7 & 189 & 3 & - \\
-31.8 .2015$. & 201 & 2 & & & & \\
\hline
\end{tabular}

Upravni sud u Rijeci

\begin{tabular}{|c|c|c|c|c|c|c|}
\hline GOD. & $\begin{array}{c}\text { UKUPNO } \\
\text { PODNESENO } \\
\text { USTAVNIH } \\
\text { TUŽBI }\end{array}$ & UKINUTO & $\begin{array}{c}\text { POTVRĐENO } \\
\text { - ODBIJENO }\end{array}$ & ODBAČENO & OBUSTAVLJENO & NERIJEŠENO \\
\hline $\begin{array}{c}1.1 .2012 . \\
-31.8 .2015 .\end{array}$ & 229 & 2 & 7 & 216 & - & 4 \\
\hline
\end{tabular}

Upravni sud u Osijeku

\begin{tabular}{|c|c|c|c|c|c|c|}
\hline GOD. & $\begin{array}{c}\text { UKUPNO } \\
\text { PODNESENO } \\
\text { USTAVNIH } \\
\text { TUŽBI }\end{array}$ & UKINUTO & $\begin{array}{c}\text { POTVRĐENO } \\
\text { - ODBIJENO }\end{array}$ & ODBAČENO & OBUSTAVLJENO & NERIJEŠENO \\
\hline $\begin{array}{c}1.1 .2012 .- \\
31.8 .2015 .\end{array}$ & 381 & 9 & 9 & 315 & 3 & 45 \\
\hline
\end{tabular}

Tabelarni prikazi ustavnih tužbi podnesenih protiv odluka prvostupanjskih upravnih sudova $i$ Visokog upravnog suda Republike Hrvatske

O ustavnoj tužbi, sukladno članku 68. citiranog Ustavnog zakona ${ }^{30}$ odlučuje vijeće tog suda sastavljeno od šest sudaca (stavak 1.), s time da vijeće sastavljeno od troje sudaca odlučuje o ustavnim tužbama kada ne postoje postupovne pretpostavke za odlučivanje, bilo da je tužba podnesena nepravodobno, podnesena od neovlaštene osobe, nedopuštena i dr. (stavak 2.). Vijeće Ustavnog suda prilikom odlučivanja o ustavnoj tužbi može odlučivati samo jednoglasno i u punom sastavu (stavak 3.). Ukoliko se u vijeću koje odlučuje o ustavnoj tužbi ne postigne jednoglasnost ili ukoliko vijeće smatra da predmet ustavne tužbe ima širi značaj, o ustavnoj tužbi odlučit će sjednica Ustavnog suda (stavak 4.).

Prilikom odlučivanja o ustavnoj tužbi vijeće odnosno sjednica Ustavnog suda

\footnotetext{
30 Vidi članak 68. Ustavnog zakona o Ustavnom sudu Republike Hrvatske.
} 
ispituje samo one povrede ustavnih prava koje su istaknute u ustavnoj tužbi. ${ }^{31}$ Ukoliko Ustavni sud utvrdi da je ustavna tužba nepravodobna, nepotpuna, nerazumljiva ili nedopuštena, odbacit će je rješenjem. ${ }^{32}$ Ustavni sud o ustavnoj tužbi meritorno odlučuje odlukom kojom tužbu usvaja ili odbija kao neosnovanu. ${ }^{33}$

Pored ustavnopravne kontrole odluka upravnih sudova donesenih $u$ „subjektivnom upravnom sporu“, u nadležnost Ustavnog suda Republike Hrvatske spada i ocjena ustavnosti odluka Visokog upravnog suda Republike Hrvatske donesenih u tzv. „objektivnom upravnom sporu“. Naime, Zakon o upravnim sporovima iz 2010. proširio je predmet upravnog spora, tako da je propisao da u predmet upravnog spora spada i ocjena zakonitosti općeg akta jedinice lokalne i područne (regionalne) samouprave, pravne osobe koja ima javnu ovlast i pravne osobe koja obavlja javnu službu. ${ }^{34}$

Mogli bismo reći kako ova ovlast Visokom upravnom sudu Republike Hrvatske daje stanovite „ustavnosudske prerogative“ jer bi kroz svoje ovlasti putem objektivnog upravnog spora, donošenjem odluka u postupku ocjene zakonitosti spomenutih općih akata, a koje odluke djeluju ergaomnes, Visoki upravni sud Republike Hrvatske trebao doprinositi normativnoj harmonizaciji pravnog poretka.

Dakle, smisao ovog postupka nije zaštita samo subjektivnih prava povodom ocjene

zakonitosti pojedinačne odluke kojom je javnopravno tijelo odlučilo o pravu, obvezi ili pravnom interesu stranke u upravnoj stvari, već ocjena objektivne zakonitosti navedenih općih akata. Za napomenuti je da je postupak ocjene zakonitosti općih akata reguliran posebnim poglavljem Zakona o upravnim sporovima (6. dio) koji se sastoji od šest članaka kojima je regulirana procedura od pokretanja postupka do odlučivanja o zakonitosti općeg akta. Sukladno odredbama članka 83. citiranog Zakona, ${ }^{35}$ postupak ocjene zakonitosti općeg akta Visoki upravni sud Republike Hrvatske pokreće na zahtjev fizičke ili pravne osobe ili skupine osoba povezanih zajedničkim interesom ako je pojedinačnom odlukom javnopravnog tijela koja se temelji na općem aktu došlo do povrede njihovih prava ili pravnog interesa, zahtjev se podnosi u roku od 30 dana od dostave odluke (stavak 1.). Postupak ocjene zakonitosti općeg akta Visoki upravni sud Republike Hrvatske može pokrenuti po službenoj dužnosti, na temelju obavijesti građana, Pučkog pravobranitelja ili na zahtjev suda (stavak 2.).

Iz evidencije Visokog upravnog suda Republike Hrvatske proizlazi da su od početka primjene Zakona o upravnim sporovima (1. siječnja 2012.) do 31. kolovoza 2015. na tom sudu zaprimljena 863 predmeta za ocjenu zakonitosti

\footnotetext{
31 Vidi članak 71., stavak 1. Ustavnog zakona o Ustavnom sudu Republike Hrvatske.

32 Vidi članak 72., stavak 1. Ustavnog zakona o Ustavnom sudu Republike Hrvatske.

33 Vidi članak 73., stavak 1. i 2. Ustavnog zakona o Ustavnom sudu Republike Hrvatske.

34 Vidi članak 3., stavak 2. Zakona o upravnim sporovima.

35 Vidi članak 83. Zakona o upravnim sporovima.
} 
općih akata od kojih je riješeno 789 predmeta, a u svezi sa 26 odluka podnesene su ustavne tužbe po kojima u 24 predmeta Ustavni sud Republike Hrvatske nije odlučivao, dok su u 2 predmeta ustavne tužbe odbačene.

\section{MOGUĆNOSTI KONTROLE ZAKONITOSTI SUDSKE UPRAVE ODNOSNO KONTROLE RADA PREDSJEDNIKA SUDOVA I SUDACA NA UPRAVNIM SUDOVIMA U REPUBLICI HRVATSKOJ}

\section{a) Kontrola zakonitosti rada sudske uprave}

Poslovi sudske uprave propisani su odredbom članka 29., stavkom 1. Zakona o sudovima, ${ }^{36}$ pa tako u poslove sudske uprave spada: osiguranje uvjeta za pravilan rad i poslovanje suda, skrb o urednom i pravodobnom obavljanju poslova u sudu, poslovi pozivanja i raspoređivanja sudaca porotnika, poslovi u svezi sa stalnim sudskim tumačima, vještacima i procjeniteljima, poslovi osiguranja podrške svjedocima i žrtvama u sudskim postupcima, postupanje po zahtjevu za zaštitu prava na suđenje u razumnom roku, poslovi ovjere isprava namijenjenih uporabi u inozemstvu, poslovi u svezi s međunarodnom pravnom pomoći i pravosudnom suradnjom, poslovi u svezi s predstavkama stranaka na rad suda, poslovi vezani uz funkcioniranje informatičkog sustava, poslovi financijsko-materijalnog poslovanja suda, poslovi praćenja naplate sudskih pristojbi, stručni poslovi u svezi s ostvarivanjem prava i dužnosti službenika i namještenika u sudu, skrb o stručnom usavršavanju sudaca, sudskih savjetnika, sudačkih vježbenika i drugih službenika i namještenika u sudu, poslovi upravljanja sudskom zgradom i nekretninama koje su dodijeljene sudu na korištenje, poslovi vođenja statistike i analize upravljačkih izvješća o radu sudaca i suda, davanje obavijesti o radu suda i drugi poslovi propisani zakonom i Sudskim poslovnikom.

Sudski poslovnik u članku $4 .{ }^{37}$ propisuje da, pored poslova propisanih Zakonom o sudovima, poslovi sudske uprave obuhvaćaju i: stručne poslove u vezi s imenovanjem, stegovnom odgovornošću, razrješenjem te ostvarivanjem drugih prava i dužnosti sudaca, poslove osiguranja uvjeta za korištenje informacijskog sustava u primjeni u poslovanju suda u skladu s pravilnikom ministra pravosuđa te poslove nadzora nad urednim i pravodobnim unosom podataka u informacijski sustav, poslove izvršenja kaznenopravnih sankcija (osim izvršenja kazne zatvora) i prekršajnopravnih sankcija i postupak s osobama protiv kojih je određen istražni zatvor, poslove izdavanja uvjerenja da se ne vodi kazneni postupak, druge poslove propisane zakonom i ovim poslovnikom.

Poslove sudske uprave obavlja predsjednik suda i prilikom obavljanja tih poslova donosi upravne i druge akte, izdaje naredbe i daje upute u okviru svojih ovlasti. ${ }^{38} \mathrm{U}$ poslovima sudske uprave predsjedniku pomažu ravnatelj sudske

\footnotetext{
36 Vidi članak 29., stavak 1. Zakona o sudovima.

37 Vidi članak 4. Sudskog poslovnika.

38 Vidi članak 31., stavak 1. Zakona o sudovima.
} 
uprave, predsjednici odjela, tajnik suda, voditelj stalne službe ili službenik kojeg odredi predsjednik suda. ${ }^{39}$

Zakonom o sudovima i Sudskim poslovnikom propisane su obveze koje su identične predsjednicima svih sudova, pa tako i upravnih sudova.

Predsjednik suda (kako prvostupanjskih upravnih sudova tako i Visokog upravnog suda Republike Hrvatske) upravlja sudom, odgovoran je za pravilno i zakonito obavljanje poslova sudske uprave u sudu, obavlja nadzor nad urednim i pravodobnim obavljanjem svih poslova u sudu te brine o učinkovitosti suda u rješavanju predmeta, a posebno o rješavanju predmeta u kojima postupak traje više od tri godine. ${ }^{40} \mathrm{U}$ tom smislu predsjednik suda dužan je do 10. prosinca tekuće godine za iduću godinu donijeti godišnji raspored poslova kojim se utvrđuje ustroj suda i podjela poslova koji se obavljaju u sudu ${ }^{41}$ te pravomoćni godišnji raspored poslova dostaviti predsjedniku neposredno višeg suda i Ministarstvu pravosuđa. ${ }^{42}$

Predsjednik suda odgovoran je i za pravilno i zakonito obavljanje poslova sudske uprave u sudu te je, osim predsjedniku Vrhovnog suda Republike Hrvatske, dužan do 31. siječnja predsjedniku neposredno višeg suda, Državnom sudbenom vijeću i Ministarstvu pravosuđa podnijeti izvješće o obavljenim poslovima sudske uprave $u$ prethodnoj godini te plan poslova sudske uprave, posebno mjera $i$ aktivnosti za unapređenje rada i učinkovitosti suda u rješavanju predmeta, kao i očekivanih rezultata rada suda za tekuću godinu. ${ }^{43}$

Nadalje, nadzor nad urednim i pravodobnim obavljanjem poslova u sudu predsjednik suda obavlja uvidom u rad sudaca i sudskih vijeća, službenika i namještenika, uvidom u spise i odluke, pregledom poslovnih dnevnika (ročišnika), upisnika, pomoćnih knjiga i upravljačkih i drugih izvješća informacijskog sustava u primjeni u poslovanju suda, nadzorom rada sudske pisarnice i drugih ustrojstvenih jedinica suda. O obavljenom nadzoru i rezultatima nadzora te poduzetim mjerama predsjednik suda dužan je najmanje jedanput mjesečno sastaviti izvješće koje će uložiti u za to osnovani spis sudske uprave. ${ }^{44}$

Predsjednik suda brine i o učinkovitosti rada suda i to na način da se prati rad sudaca. ${ }^{45} \mathrm{U}$ tom smislu, predsjednik suda u kojem sudac obnaša sudačku dužnost rješenjem, koje je dužan donijeti najkasnije do 31. ožujka tekuće godine, utvrđuje za prethodnu kalendarsku godinu je li sudac ispunio svoje sudačke obveze prema kriterijima iz članka 97. Zakona. Ako predsjednik suda utvrdi da sudac bez opravdanog razloga nije donio u jednogodišnjem razdoblju broj odluka utvrđen Okvirnim mjerilima za rad sudaca ili je neuredno obnašao sudačku dužnost, dužan

\footnotetext{
39 Vidi članak 30., stavak 3. Zakona o sudovima.

40 Vidi članak 5., stavak 1. Sudskog poslovnika.

41 Vidi članak 22., stavak 1. i 3. Sudskog poslovnika.

42 Vidi članak 10., stavak 2. Zakona o sudovima.

43 Vidi članak 33., stavak 1. - 3. Zakona o sudovima.

44 Vidi članak 5., stavak 3. i 4. Sudskog poslovnika.

45 Vidi članak 95., stavak 1. - 5. Zakona o sudovima.
} 
je protiv takvog suca pokrenuti stegovni postupak, sukladno Zakonu o Državnom sudbenom vijeću. Protiv predsjednika suda stegovni postupak pokreće predsjednik neposredno višeg suda, odnosno predsjednik Vrhovnog suda Republike Hrvatske i ministar pravosuđa. Ako predsjednik suda utvrdi da sudac zbog opravdanih razloga u jednogodišnjem razdoblju nije donio broj odluka utvrđen Okvirnim mjerilima za rad sudaca, dužan je u obrazloženju rješenja iz stavka 1. ovog članka navesti o kojim se opravdanim razlozima radi te rješenje dostaviti predsjedniku neposredno višeg suda.

Svatko ima pravo da zakonom ustanovljeni neovisni i nepristrani sud pravično i u razumnom roku odluči o njegovim pravima i obvezama ili o sumnji ili optužbi zbog kažnjivog djela, ${ }^{46}$ pa je predsjednik suda dužan brinuti da se odluke u predmetima pred tim sudom donesu u razumnom roku. $\mathrm{U}$ tom smislu predsjednik suda je prvostupanjsko tijelo sudske uprave koje odlučuje o zahtjevima za zaštitu prava na suđenje u razumnom roku u smislu članka 65. do 67. Zakona o sudovima. ${ }^{47}$

Ukoliko predsjednik prvostupanjskog upravnog suda utvrdi da je zahtjev za zaštitu prava na suđenje u razumnom roku osnovan, odredit će rok, ne duži od šest mjeseci, osim ako okolnosti ne nalažu određivanje dužeg roka, u kojem sudac predmet mora riješiti. Ako odluka u određenom roku ne bude donesena, stranka može Visokom upravnom sudu Republike Hrvatske podnijeti zahtjev za isplatu primjerene naknade zbog povrede prava na suđenje u razumnom roku, o kojem zahtjevu će odlučiti rješenjem sudac pojedinac.

Pored svih nabrojanih dužnosti koje imaju svi predsjednici sudova, predsjednik Visokog upravnog suda Republike Hrvatske ujedno je i drugostupanjsko tijelo u poslovima sudske uprave iz ovlasti predsjednika upravnog suda te u poslovima sudske uprave nadzire rad nižih sudova sa svojeg područja uvidom u podatke o njihovu radu, a prema potrebi i određivanjem neposrednog nadzora. ${ }^{48}$

U obavljanju svoje kontrolne uloge predsjednik Visokog upravnog suda Republike Hrvatske odredit će, u pravilu jednom godišnje, provođenje nadzora nad urednim obavljanjem poslova sudaca i sudova na području svoje nadležnosti. Nadzor obavljaju suci Visokog upravnog suda Republike Hrvatske određeni od predsjednika tog suda. Pisano izvješće o obavljenom nadzoru suci su dužni u roku od 30 dana dostaviti predsjedniku Visokog upravnog suda Republike Hrvatske, koji će izvješće dostaviti predsjedniku nadziranog suda, predsjedniku Vrhovnog suda Republike Hrvatske, Državnom sudbenom vijeću i Ministarstvu pravosuđa. ${ }^{49}$

Provođenje nadzora od strane sudaca Visokog upravnog suda Republike Hrvatske, a na zahtjev predsjednika tog suda, predstavlja oblik neposredne kontrole zakonitosti rada sudske uprave, suda, sudaca odnosno predsjednika suda. Njome se u bitnome kontrolira jesu li u radu sudske uprave, suda i sudaca

\footnotetext{
46 Vidi članak 4. Zakona o sudovima.

47 Vidi članak 65. - 67. Zakona o sudovima.

48 Vidi članak 8. Sudskog poslovnika.

49 Vidi članak 28. Zakona o sudovima.
} 
poštovane odredbe Zakona o sudovima, Sudskog poslovnika i drugih zakona. Osobito se tu može naglasiti da se provjerava i to dodjeljuju li sepredmeti na prvostupanjskom upravnom sudu sukladno Sudskom poslovniku, odredbama 26. i $27 .{ }^{50}$ jer povreda propisa o dodjeljivanju predmeta u rad predstavlja jedan od razloga za pokretanje stegovnog postupka protiv predsjednika prvostupanjskog suda, od strane predsjednika Visokog upravnog suda Republike Hrvatske pred Državnim sudbenim vijećem, te može biti razlog i za njegovo razrješenje.

Međutim, predsjednik Visokog upravnog suda Republike Hrvatske može i posredno kontrolirati zakonitost rada sudske uprave, suda i sudaca. Navedeno se postiže kroz obvezu predsjednika prvostupanjskih upravnih sudova da dostave pravomoćan godišnji raspored poslova. ${ }^{51}$ Napominjem da pritom predsjednik Visokog upravnog suda Republike Hrvatske, kao više tijelo sudske uprave, može po službenoj dužnosti ili povodom prigovora i primjedbi izmijeniti ili dopuniti godišnji raspored poslova, ukinuti ga ili vratiti na dopunu predsjedniku suda koji ga je donio, odnosno potvrditi doneseni godišnji raspored poslova. ${ }^{52}$

Posredna kontrola zakonitosti rada sudske uprave prvostupanjskih upravnih sudova postiže se i kroz obvezu predsjednika prvostupanjskih sudova da predsjedniku Visokog upravnog suda Republike Hrvatske podnesu izvješće o obavljenim poslovima sudske uprave u prethodnoj godini te plan poslova sudske uprave, posebno mjera i aktivnosti za unapređenje rada i učinkovitosti suda u rješavanju predmeta, kao i očekivanih rezultata rada suda za tekuću godinu. ${ }^{53}$ Time u svezi posebno se ističe da predsjednik Visokog upravnog suda Republike Hrvatske može, sukladno članku 89., stavku 3. Sudskog poslovnika, ${ }^{54}$ u bilo kojem trenutku, zatražiti od predsjednika prvostupanjskih upravnih sudova statističke podatke o radu suda.

Predsjednik Visokog upravnog suda Republike Hrvatske jest drugostupanjsko tijelo sudske uprave povodom žalbe suca prvostupanjskog upravnog suda na rješenje kojim je predsjednik prvostupanjskog upravnog suda odbio prigovor na rješenje o ispunjavanju sudačke obveze ${ }^{55}$ i može donijeti odluku kojom potvrđuje rješenje predsjednika prvostupanjskog upravnog suda ili prihvatiti žalbu i donijeti novo rješenje.

Nadalje, predsjednik Visokog upravnog suda Republike Hrvatske odlučuje povodom žalbe podnositelja zahtjeva na rješenje predsjednika prvostupanjskog upravnog suda kojim je odbijen zahtjev za zaštitu prava na suđenje u razumnom roku $^{56}$ te može žalbu odbiti kao neosnovanu i potvrditi prvostupanjsko rješenje ili preinačiti rješenje.

50 Vidi članak 26. i 27. Sudskog poslovnika.

51 Vidi članak 10., stavak 2. Zakona o sudovima.

52 Vidi članak 25., stavak 4. Sudskog poslovnika.

53 Vidi članak 33. Sudskog poslovnika.

54 Vidi članak 89., stavak 3. Sudskog poslovnika.

55 Vidi članak 95., stavak 7. Zakona o sudovima.

56 Vidi članak 67. Zakona o sudovima. 
Svatko ima pravo podnijeti pisanu ili usmenu predstavku predsjedniku suda na rad suda ili suca zbog odugovlačenja postupka u kojem je stranka ili ima pravni interes, odnosno zbog nedoličnog ili neprimjerenog ponašanja suca i drugog zaposlenika u službenim odnosima sa strankom koje je suprotno etičkom kodeksu i dobiti odgovor na njih, a predsjednik suda dužan je odgovoriti na predstavku najkasnije u roku od 30 dana od dana njezina zaprimanja. ${ }^{57}$

Praksa je pokazala da stranke vrlo često predstavke, koje se odnose na rad prvostupanjskih upravnih sudova, šalju predsjedniku Visokog upravnog suda Republike Hrvatske. U tom će slučaju predsjednik Visokog upravnog suda Republike Hrvatske zatražiti očitovanje na navode predstavke od predsjednika prvostupanjskog upravnog suda čime ponovno dobiva uvid, ne samo u rad sudske uprave već i samih sudaca prvostupanjskih upravnih sudova.

Predsjednik suda odgovoran je za zakoniti rad sudske uprave i suda u cjelini, a svako odstupanje od zakonitosti može biti razlog za njegovo razrješenje. Prijedlog za razrješenje predsjednika suda mogu podnijeti predsjednik neposredno višeg suda, predsjednik Vrhovnog suda Republike Hrvatske i ministar pravosuđa, ${ }^{58}$ a o njemu odlučuje Državno sudbeno vijeće. U Zakonu o Državnom sudbenom vijeću taksativno su nabrojani razlozi kada će Vijeće razriješiti dužnosti predsjednika suda. Kao razlozi navedeni su: kada poslove sudske uprave obavlja protivno propisima, kada ne poduzima mjere iz svojih ovlasti za učinkovit rad suda, kada bez opravdanog razloga ne ostvaruje program izložen u postupku imenovanja na dužnost predsjednika suda, kada propuštanjem nadzora, ili neposredno, krši propise o dodjeljivanju predmeta u rad, kada kršenjem propisa ili na drugi način povrijedi načelo neovisnosti suca u suđenju, kada ne podnese zahtjev za pokretanje postupka zbog počinjenog stegovnog djela u zakonom predviđenim slučajevima odnosno zloupotrebljava svoj položaj ovlaštenog predlagatelja pokretanja stegovnog postupka, kada je svojim ponašanjem ili na drugi način nanio štetu ugledu suda ili sudačkoj dužnosti, kada je privremeno udaljen sa sudačke dužnosti.

Sve do sada rečeno na odgovarajući način odnosi se i na rad predsjednika Visokog upravnog suda Republike Hrvatske, sudske uprave Visokog upravnog suda Republike Hrvatske, s time da je više tijelo sudske uprave u tom slučaju predsjednik Vrhovnog suda Republike Hrvatske.

b) Kontrola zakonitosti rada sudaca upravnih sudova

Kontrola zakonitosti rada sudaca prvostupanjskih upravnih sudova od strane Visokog upravnog suda Republike Hrvatske, u užem smislu postiže se odlučivanjem o žalbi na njihove odluke (presude i rješenja). Međutim, Zakonom o sudovima i Sudskim poslovnikom određeni su i drugi mehanizmi koji Visokom upravnom sudu Republike Hrvatske, njegovim sucima i predsjedniku omogućavaju kontrolu zakonitosti rada prvostupanjskih upravnih sudaca i reagiranje na utvrđene nepravilnosti.

57 Vidi članak 4., stavak 3. Zakona o sudovima.

58 Vidi članak 85. Zakona o Državnom sudbenom vijeću. 
Visoki upravni sud Republike Hrvatske, kao viši sud, sukladno odredbama Zakona o sudovima dužan je nižem sudu ukazati na nedostatke koje je uočio prigodom odlučivanja o pravnom lijeku ili na drugi način i može tražiti od nižeg suda podatke u svezi s primjenom zakona, problemima koji se javljaju u suđenju, praćenju i proučavanju sudske prakse te druge podatke, a može izvršiti i neposredan nadzor nad radom tog suda i pojedinih sudaca, kao i organizirati zajedničke sastanke radi razmatranja navedenih pitanja. Prigodom provedbe tih ovlaštenja ne smije ni na koji način utjecati na neovisnost i slobodu suda nižeg stupnja u donošenju odluke u pojedinom predmetu. ${ }^{59}$

Na sjednicama sudskog odjela Visokog upravnog suda Republike Hrvatske razmatraju se pitanja od interesa za rad odjela tog Suda, a posebice organizacije unutarnjeg poslovanja, sporna pravna pitanja, ujednačavanje sudske prakse i pitanja važna za primjenu propisa iz pojedinih pravnih područja te pitanja praćenja rada i stručnog usavršavanja sudaca, sudskih savjetnika i sudačkih vježbenika raspoređenih na rad u odjel kao i pitanja od zajedničkog interesa za sudove nižeg stupnja s područja tih sudova. ${ }^{60}$

Sjednica odjela ili sudaca saziva se i kad se utvrdi da o pitanjima primjene zakona postoje razlike u shvaćanjima između pojedinih odjela, vijeća ili sudaca ili kad u jednom odjelu vijeće ili sudac odstupi od ranije prihvaćenog pravnog shvaćanja. Pravno shvaćanje prihvaćeno na sjednici svih sudaca odnosno sudskog odjela Visokog upravnog suda Republike Hrvatske, obvezno je za sva drugostupanjska vijeća ili suce pojedince tog odjela, odnosno suda ${ }^{61}$ a zbog hijerarhijske snage djeluje i na praksu prvostupanjskih upravnih sudova.

Predsjednik Visokog upravnog suda Republike Hrvatske posredno prati rad sudaca prvostupanjskih sudova kroz statistička izvješća koja dostavljaju predsjednici prvostupanjskih upravnih sudova, kroz izvješća o ispunjenju sudačke obveze (odnosno odlučujući povodom žalbe suca prvostupanjskog upravnog suda na rješenje kojim je predsjednik prvostupanjskog upravnog suda odbio prigovor na rješenje o ispunjavanju sudačke obveze), kroz odlučivanje o žalbi na rješenje predsjednika prvostupanjskog upravnog suda kojim je odbijen zahtjev za zaštitu prava na suđenje u razumnom roku.

Zakonom o sudovima, člancima 89. do 93., kao i Kodeskom sudačke etike ${ }^{62}$ propisane su dužnosti suca te etička načela koje je sudac dužan slijediti u svome radu. Osnovna načela nužna za uspješno obnašanje sudačke dužnosti jesu među ostalima: ustavnost i zakonitost, humanost i etika, neovisnost, nepristranost, stručnost, jednakost, dostojanstvo sudačkog poziva, odgovornost, marljivost itd. Osobito se tu ističe načelo odgovornosti i marljivosti.

59 Vidi članak 27. Zakona o sudovima.

60 Vidi članak 38. Zakona o sudovima.

61 Vidi članak 40. Zakona o sudovima.

${ }^{62}$ Kodeks sudačke etike (Narodne novine, broj: 131/06) donesen na Vrhovnom sudu Republike Hrvatske 26. listopada 2006. na sjednici Vijeća koje čine predsjednici svih Sudačkih vijeća u Republici Hrvatskoj. 
Odgovornost znači da je sudac dužan predmete kojima je zadužen rješavati redoslijedom tako da ne daje prednost nekoj od stranaka u postupku. Sudac je dužan paziti da u njegovu radu na pojedinim predmetima nema nepotrebnog zastoja te je dužan u najkraćem mogućem roku provesti postupak u kojem odlučuje. Sudac je odgovoran za racionalno raspoređivanje posla u okvirima pune iskorištenosti radnog vremena. Sudac ne smije otkriti povjerljive obavijesti za koje sazna tijekom obnašanja dužnosti, osim ako to zahtijeva službena dužnost.

S druge strane, marljivost znači da je sudac dužan uložiti sav svoj trud i znanje u ostvarenje najboljih radnih rezultata, pazeći pritom da količina ostvarenih zadataka ne bude na štetu njihove kvalitete. Sudac je dužan, u skladu sa svojim mogućnostima i interesima, posvetiti se ne samo radnim zadacima i odgovornostima vezanima za sud i donošenje sudskih odluka, već i drugim zadacima važnima za sudački poziv i funkcioniranje suda. Izvansudske aktivnosti suca ne smiju ometati njegovo redovito i uredno obnašanje sudačke dužnosti.

Okvirnim mjerilima za rad sudaca propisan je broj odluka koje su suci svakog suda u Republici Hrvatskoj, pa tako i upravnih sudova i Visokog upravnog suda Republike Hrvatske, dužni donijeti u tijeku jedne kalendarske godine.

Prekršajni sudovi, Visoki prekršajni sud Republike Hrvatske, upravni sudovi, Visoki upravni sud Republike Hrvatske, Visoki trgovački sud Republike Hrvatske i Vrhovni sud Republike Hrvatske dužni su Ministarstvu pravosuđa elektroničkim putem u roku od 15 dana po isteku svakog tromjesečja dostavljati podatke o ukupnom broju primljenih i riješenih predmeta u isteklom tromjesečju i ukupnom broju neriješenih predmeta, podatke o ukupnom broju predmeta zaprimljenih u rad suda prije 3 ili više godina, kao i podatke o pojedinačnom radu sudaca u isteklom tromjesečju. Sudovi su dužni u skladu s posebnim propisima ili na traženje, dostavljati višim tijelima sudske uprave i Ministarstvu pravosuđa i druge statističke podatke o svom radu. ${ }^{63}$

Sukladno navedenome, predsjednik Visokog upravnog suda Republike Hrvatske može, kroz statističke podatke, pratiti pridržavaju li se suci prvostupanjskih upravnih sudova Okvirnih mjerila za rad sudaca u pogledu broja donesenih odluka.

Također, predsjednik Visokog upravnog suda Republike Hrvatske može pratiti rad sudaca prvostupanjskih sudova i kroz dostavljena rješenja o ispunjavanju sudačke obveze pri čemu se pozornost pridaje: broju odluka koje je sudac donio u odnosu na broj odluka koje je trebao donijeti na temelju Okvirnih mjerila za rad sudaca, rezultatu rada po vrstama predmeta u apsolutnim brojevima i postotku, poštovanju rokova za donošenje i izradu odluka, kvaliteti odluka povodom izjavljenih pravnih lijekova (potvrđene, ukinute ili preinačene u apsolutnom broju i postotku u odnosu na ukupan broj donesenih odluka, u odnosu na broj odluka u

63 Vidi članak 89. Sudskog poslovnika. 
predmetima u kojima je izjavljen pravni lijek te broj odluka ukinutih zbog bitnih povreda postupka), drugim aktivnostima suca. ${ }^{64}$

Ako predsjednik prvostupanjskog upravnog suda utvrdi da sudac bez opravdanog razloga nije donio u jednogodišnjem razdoblju broj odluka utvrđen Okvirnim mjerilima za rad sudaca ili je neuredno obnašao sudačku dužnost, dužan je protiv takvog suca pokrenuti stegovni postupak, sukladno Zakonu o Državnom sudbenom vijeću. Protiv predsjednika suda, koji pored predsjedničke dužnosti obavlja i sudačku dužnost, stegovni postupak pokreće predsjednik neposredno višeg suda. Ako predsjednik suda utvrdi da sudac zbog opravdanih razloga u jednogodišnjem razdoblju nije donio broj odluka utvrđen Okvirnim mjerilima za rad sudaca, dužan je u obrazloženju rješenja navesti o kojim se opravdanim razlozima radi te rješenje dostaviti predsjedniku neposredno višeg suda. ${ }^{65}$

Predsjednik Visokog upravnog suda Republike Hrvatske može pratiti ažurnost rada svakog suca prvostupanjskog suda i kroz institut zaštite prava na suđenje u razumnom roku. Svaka stranka koja smatra da nadležni sud nije odlučio u razumnom roku o njezinu pravu ili obvezi ili sumnji ili optužbi za kažnjivo djelo ima pravo na sudsku zaštitu i to podnošenjem zahtjeva za zaštitu prava na suđenje u razumnom roku i zahtjeva za isplatu primjerene naknade zbog povrede prava na suđenje u razumnom roku. $O$ žalbi protiv rješenja kojim je predsjednik prvostupanjskog upravnog suda odbio zahtjev stranke za zaštitu prava na suđenje u razumnom roku odlučuje predsjednik neposredno višeg suda, dakle predsjednik Visokog upravnog suda Republike Hrvatske. Odlučujući o žalbi, predsjednik Visokog upravnog suda Republike Hrvatske ispituje zakonitost rješenja predsjednika prvostupanjskog upravnog suda kroz žalbene navode te neposrednim uvidom $u$ spis predmeta. Time dobija neposredni uvid $u$ rad suca $u$ tom predmetu kao i ažurnost rada. Predsjednik Visokog upravnog suda Republike Hrvatske može žalbu odbiti kao neosnovanu i potvrditi prvostupanjsko rješenje ili preinačiti rješenje. ${ }^{66}$

Suci Visokog upravnog suda Republike Hrvatske, a time posredno i predsjednik Suda, također mogu dobiti uvid u ažurnost sudaca prvostupanjskih upravnih sudova kroz zahtjeve stranaka za isplatu primjerene naknade zbog povrede prava na suđenje u razumnom roku. ${ }^{67} \mathrm{O}$ njima odlučuje sudac pojedinac rješenjem $\mathrm{u}$ roku od 6 mjeseci. Sudac će odrediti rok u kojem sud pred kojim je postupak u tijeku mora riješiti predmet te odrediti primjerenu naknadu koja pripada podnositelju zbog povrede prava na suđenje u razumnom roku. ${ }^{68}$ Rješenje kojim se dosuđuje isplata primjerene naknade zbog povrede prava na suđenje u razumnom roku dostavlja se odmah nakon pravomoćnosti predsjedniku suda pred kojim je došlo do povrede prava na suđenje u razumnom roku, predsjedniku Vrhovnog

\footnotetext{
64 Vidi članak 97. Zakona o sudovima.

65 Vidi članak 95. Zakona o sudovima.

66 Vidi članak 67. Zakona o sudovima.

67 Vidi članak 68. Zakona o sudovima.

68 Vidi članak 69. Zakona o sudovima.
} 
suda Republike Hrvatske i Ministarstvu pravosuđa. Naknada se isplaćuje iz sredstava državnog proračuna. Ako predmet ne bude riješen u određenom roku određenim rješenjem Visokog upravnog suda Republike Hrvatske, predsjednik prvostupanjskog upravnog suda dužan je o razlozima u roku od 15 dana od isteka određenog roka dostaviti pisano izvješće predsjedniku Visokog upravnog suda Republike Hrvatske i Ministarstvu pravosuđa.

Sudačka dužnost je stalna, a suci imaju imunitet u skladu sa zakonom i ne mogu biti pozvani na odgovornost za izraženo mišljenje ili glasovanje pri donošenju sudbene odluke, osim ako se radi o kršenju zakona od strane suca koje je kazneno djelo. ${ }^{69}$ Ipak, sudac će biti razriješen sudačke dužnosti zbog nekoliko razloga i to: ako to sam zatraži, ako trajno izgubi sposobnost obavljati svoju dužnost, ako bude osuđen za kazneno djelo koje ga čini nedostojnim obavljanja sudačke dužnosti, ako u skladu sa zakonom, zbog počinjenoga teškog stegovnog djela, tako odluči Državno sudbeno vijeće i kad navrši sedamdeset godina. ${ }^{70}$

S aspekta kontrole zakonitosti rada prvostupanjskih upravnih sudaca bitan je dio koji se odnosi na počinjenje teškog stegovnog djela. Sudac odgovara za počinjena stegovna djela ${ }^{71} \mathrm{i}$ to: neuredno obnašanje sudačke dužnosti, nepostupanje po odluci donesenoj u postupku za zaštitu prava na suđenje u razumnom roku, obnašanje službe, poslova ili djelatnosti nespojivih sa sudačkom dužnošću, izazivanje poremećaja u radu suda koji znatno utječu na djelovanje sudbene vlasti, povreda službene tajne u svezi s obnašanjem sudačke dužnosti, nanošenje štete ugledu suda ili sudačke dužnosti na drugi način, nepodnošenje imovinske kartice ili neistinito prikazivanje podataka u imovinskoj kartici, nepodvrgavanje prosudbi tjelesnih i duševnih svojstava radi ocjene sposobnosti za obnašanje sudačke dužnosti.

Pod neurednim obavljanjem sudačke dužnosti smatra se osobito ako sudac bez opravdanog razloga ne izrađuje i ne otprema sudske odluke, ako je sudačko vijeće ocijenilo rad suca ocjenom nezadovoljavajuće obnaša dužnost, ako je bez opravdanog razloga broj odluka koje je sudac donio u jednogodišnjem razdoblju bitno ispod broja odluka utvrđenih Okvirnim mjerilima za rad sudaca, ako sudac u rješavanju predmeta bez opravdanog razloga bitno odstupa od redoslijeda njihova zaprimanja u sudu, odnosno ne vodi računa o njihovoj hitnosti. ${ }^{72}$

Ako postoji osnovana sumnja da je sudac počinio stegovno djelo, predsjednik suda ili osoba ovlaštena za obavljanje poslova sudske uprave u sudu u kojem obnaša sudačku dužnost dužna je protiv tog suca pokrenuti stegovni postupak, ${ }^{73}$ a mogu ga pokrenuti i ministar nadležan za poslove pravosuđa, predsjednik neposredno višeg suda, predsjednik Vrhovnog suda Republike Hrvatske i sudačko vijeće.

69 Vidi članak 122. Ustava Republike Hrvatske.

70 Vidi članak 123. Ustava Republike Hrvatske.

71 Vidi članak 62. Zakona o Državnom sudbenom vijeću.

72 Vidi članak 62. Zakona o Državnom sudbenom vijeću.

73 Vidi članak 67. Zakona o Državnom sudbenom vijeću. 
Za počinjena stegovna djela mogu se izreći stegovne kazne: ukor, novčana kazna do jedne trećine plaće ostvarene $\mathrm{u}$ prethodnom mjesecu $\mathrm{u}$ vremenu od jednog do tri mjeseca, novčana kazna do jedne trećine plaće ostvarene u prethodnom mjesecu u vremenu od četiri do šest mjeseci, novčana kazna do jedne trećine plaće ostvarene u prethodnom mjesecu u vremenu od sedam do dvanaest mjeseci. $^{74}$

Pored stegovne odgovornosti, sudac može i materijalno odgovarati za štetu koja je nastala njegovim nezakonitim ili nepravilnim radom. ${ }^{75}$ Republika Hrvatska neposredno odgovara za štetu koju stranci u postupku nanese sudac svojim nezakonitim ili nepravilnim radom u obnašanju sudačke dužnosti. Međutim, Republika Hrvatska zatražit će od suca: povrat isplaćene naknade samo kad je sudac štetu učinio namjerno ili iz krajnje nepažnje, povrat isplaćene naknade zbog povrede prava na suđenje u razumnom roku ako je povreda nastala namjerom ili krajnjom nepažnjom suca.

Kroz ove zakonske odredbe dat je uvid na koji način predsjednik Visokog upravnog suda Republike Hrvatske može pratiti rad sudaca prvostupanjskog suda, kao i reagirati na eventualno uočene nepravilnosti. Sve ove zakonske odredbe primjenjuju se i na suce Visokog upravnog suda Republike Hrvatske, s time da je njihovo „nadzorno tijelo“ predsjednik Vrhovnog suda Republike Hrvatske te Vrhovni sud Republike Hrvatske općenito.

\section{ZAKLJUČAK}

U pravnom poretku Republike Hrvatske postoje različite vrste kontrolnih mehanizama za nadzor djelovanja upravnih sudova, odnosno predsjednika i sudaca tih sudova. Kontrolni mehanizmi koji omogućavaju kontrolu zakonitosti odluka upravnih sudova propisani su osnovnim procesnim zakonom kojim je reguliran upravni spor u Republici Hrvatskoj tj. Zakonom o upravnim sporovima, dok je mogućnost preispitivanja ustavnosti odluka upravnih sudova pred Ustavnim sudom Republike Hrvatske regulirana Ustavom odnosno Ustavnim zakonom o Ustavnom sudu Republike Hrvatske. Pored spomenutih kontrolnih mehanizama koji omogućuju kontrolu zakonitosti i ustavnosti odluka upravnih sudova, postoji drugi spektar kontrolnih mehanizama koji omogućava nadzor rada sudaca i predsjednika sudova iz perspektive organizacijske regulative. Naime, organizacijskim propisima (Zakon o sudovima, Zakon o Državnom sudbenom vijeću, Sudski poslovnik i Kodeks sudačke etike), propisani su kontrolni mehanizmi koji trebaju osigurati efikasan nadzor zakonitosti rada sudaca i predsjednika upravnih sudova u kontekstu i u okviru kriterija propisanih općim organizacijskim propisima koji se, osim na upravne sudove, odnose i na sve sudove u Republici Hrvatskoj. Iako se radi o potpuno dva odvojena spektra kontrolnih mehanizama, oni se međusobno prožimaju i u ukupnosti čine harmoniziranu cjelinu, iz koje

74 Vidi članak 63. Zakona o državnom sudbenom vijeću.

75 Vidi članak 105. Zakona o sudovima. 
deriviraju „pravila djelovanja“ sudaca i predsjednika sudova čije je poštovanje conditio sine qua non za efikasan rad upravnih sudova u Republici Hrvatskoj.

\section{ADMINISTRATIVE COURTS CONTROL MECHANISMS OF ACTION}

In this paper the author analyses the control mechanisms of administrative court activity. The author considers them in their complexity and inclusiveness through control mechanisms which enable constitutionality and legality control of court decisions and through the control mechanisms proscribed by organisational regulations the aim of which is the control of the legality of judges' and presidents' of court work. The first spectre of control mechanisms mainly derives from the fundamental law which regulates administrative dispute (Administrative Dispute Act), and partly from the provisions of the Constitution and constitutional law on the Constitutional Court of the Republic of Croatia. The other spectre of control mechanisms is archetypically connected to organisational provisions. Even though these two spectres of control mechanisms emerge from different kinds of provisions, these two together undoubtedly constitute one complementary whole of control mechanisms.

Key words: control mechanisms, administrative courts, supervision, evaluation of the legality of decisions, court administration 